\title{
Silibinin inhibits prostate cancer invasion, motility and migration by suppressing vimentin and MMP-2 expression
}

\author{
Kai-jie WU ${ }^{1}$, Jin ZENG ${ }^{1}$, Guo-dong ZHU ${ }^{1}$, Lin-lin ZHANG ${ }^{1}$, Dong ZHANG ${ }^{1}$, Lei $\mathrm{LI}^{1}$, Jin-hai FAN ${ }^{1}$, Xin-yang WANG ${ }^{2}$, Da-lin HE ${ }^{1, *}$ \\ ${ }^{1}$ Department of Urology, First Affiliated Hospital of Medical School, Xi'an Jiaotong University, Xi'an 710061, China; ${ }^{2}$ Oncology Research \\ Lab, Key Laboratory of Environment and Genes Related to Diseases, Ministry of Education of People's Republic of China, Xi'an \\ 710061, China
}

\begin{abstract}
Aim: Silibinin is known to exert growth inhibition and cell death together with cell cycle arrest and apoptosis in human prostate cancer cells. Whether silibinin could inhibit the invasion, motility and migration of prostate cancer cells remains largely unknown. This study was designed to evaluate this efficacy and possible mechanisms using a novel highly bone metastatic $\mathrm{ARCaP}_{\mathrm{M}}$ cell model. Methods: Four prostate cancer cell lines, LNCaP, PC-3, DU145, and ARCaP $\mathrm{M}_{\mathrm{M}}$, were used in this study. These cells were treated with increasing concentrations of silibinin (50, 100, and $200 \mu \mathrm{mol} / \mathrm{L})$ for different periods of time. After treatment, cell viabilities of four prostate cancer cells were compared by MTT assay. Alterations of $\mathrm{ARCaP}_{\mathrm{M}}$ cell invasion, motility and migration were assessed by cell invasion, motility and wound healing assays. The changes of vimentin expression were observed by Western blotting and immunofluorescence staining, and the expression of MMP-2, MMP-9, and UPA was analyzed by reverse transcription-polymerase chain reaction (RT-PCR).

Results: ARCaP cells showed less sensitivity to the growth inhibition of pharmacological doses of silibinin than LNCaP, PC-3, and DU145 cells. However, silibinin exerted significant dose- and time-dependent inhibitory effects on the invasion, motility and migration of $\mathrm{ARCaP}_{\mathrm{M}}$ cells. Furthermore, the expression of vimentin and MMP-2, but not MMP-9 or uPA, was down-regulated in a dose- and timedependent manner after treatment of silibinin.

Conclusion: This study shows that silibinin could inhibit the invasion, motility and migration of ARCaP $\mathrm{M}_{\mathrm{M}}$ cells via down-regulation of vimentin and MMP-2 and therefore may be a promising agent against prostate cancer bone metastasis.
\end{abstract}

Keywords: silibinin; prostate cancer; invasion; motility; migration; vimentin; MMP-2

Acta Pharmacologica Sinica (2009) 30: 1162-1168; doi: 10.1038/aps.2009.94; published online 6 July 2009

\section{Introduction}

Prostate cancer is one of the most commonly diagnosed cancers and the second leading cause of death in men in Western countries $^{[1]}$. Surgical and hormonal therapies have shown beneficial effects for early-stage, hormone-responsive disease. However, few treatment options are available for more aggressive hormone-independent or hormone-refractory prostate cancer that is resistant to chemotherapy and radiotherapy ${ }^{[2]}$. Therefore, more effort must be devoted to developing novel agents that target these unique characteristics of prostate cancer. In this regard, several nontoxic phytochemicals, including silibinin, have shown promising therapeutic and preventive efficacy against prostate cancer ${ }^{[3]}$.

\footnotetext{
* To whom correspondence should be addressed. E-mail dalinhe@yahoo.cn
}

Received 2009-03-02 Accepted 2009-05-07
Silibinin, the major active constituent of silymarin isolated from milk thistle (Silybum marianum), has shown strong anticancer efficacy against both androgen-dependent and androgen-independent prostate cancer. This phytochemical is currently being used in a phase I/II clinical trial for treatment of prostate cancer ${ }^{[4]}$. Silibinin inhibited the proliferation of human prostate cancer LNCaP, PC-3, and DU145 cells in vitro, and oral silibinin suppressed the growth of PC-3 and DU145 xenografts in nude mice and transgenic adenocarcinoma of mouse prostate (TRAMP) in vivo ${ }^{[5-10]}$. Extensive studies have shown the multi-targeted molecular mechanisms underlying therapeutic actions of silibinin in prostate cancer, and silibinin could target the IGF1-IGFBP3 axis and the cyclin-dependent kinase (CDK)-cyclin-CDK inhibitor axis to inhibit cell proliferation, as well as activate the caspase pathway to induce apoptosis $^{[5-10]}$. In addition, several recent studies have also shown the anti-metastatic activities of silibinin in prostate cancer. It 
has been reported that silibinin could exert inhibitory effects on the viability, motility and adhesion of PC-3 cells in vitro ${ }^{[11]}$, and inhibit tumor growth, progression, local invasion, and distant metastasis involving suppression of tumor angiogenesis and epithelial-mesenchymal transition in the TRAMP mouse model ${ }^{[12]}$. However, the mechanisms by which silibinin exerts its anti-metastatic effects are largely unknown.

The propensity of prostate cancer to skeletal metastases is well recognized, and most patients who die from prostate cancer have metastatic bone disease ${ }^{[13]}$. The ARCaP model was established from the ascites fluid of a patient with metastatic prostate cancer and could represent a continuum of prostate cancer progression closely mimicking the pathophysiology of advanced and lethal clinic human prostate cancer bone metastasis. $\mathrm{ARCaP}_{\mathrm{M}}$, a derivative $\mathrm{ARCaP}$ cell subclone, exhibited a spindle-shaped mesenchymal morphology with increased cell motility, invasion and migration in vitro. Furthermore, $\mathrm{ARCaP}_{\mathrm{M}}$ cells displayed a predilection to metastasize to various bone sites with increased incidence rates and shorter latency periods in SCID mice ${ }^{[14]}$. Thus, this cell model appears appropriate for screening and developing new therapeutic agents against prostate cancer bone metastasis. In this study, we evaluated the anti-metastatic activities of silibinin in prostate cancer using this unique model and explored its underlying molecular mechanisms by detecting several key molecules related to cancer invasion and metastasis, such as vimentin, matrix metalloproteinase-2 (MMP-2), matrix metalloproteinase-2 (MMP-9) and urokinase-type plasminogen activator (uPA).

\section{Materials and methods}

\section{Cell culture and silibinin treatment}

Human prostate cancer cells LNCaP, PC-3, DU145 and $\mathrm{ARCaP}_{\mathrm{M}}$ provided by Prof Leland WK Chung (Emory University School of Medicine, Atlanta, GA, USA) were maintained in RPMI 1640 or DMEM (Gibco, San Diego, CA, USA) supplemented with $10 \%(v / v)$ fetal bovine serum (FBS, Sijiqing, Hangzhou, China) at $37{ }^{\circ} \mathrm{C}$ in a humidified $5 \% \mathrm{CO}_{2}$ incubator. For silibinin treatment, appropriate volumes of stock solution (0.05 mol/L in DMSO) of silibinin (both from Sigma, St Louis, MO, USA) were added to the medium to achieve the indicated concentrations $(50,100$, and $200 \mu \mathrm{mol} / \mathrm{L})$ and were then incubated with cells for the indicated periods of time $(24,48,72$, and $96 \mathrm{~h}$ ).

\section{Determination of cell viability by MTT assay}

To compare the sensitivities of different prostate cancer cells to silibinin treatment, 3-(4,5-dimethylthiazol-2-yl)-2,5diphenyltetrazolium bromide (MTT, Sigma, St Louis, MO, USA) proliferation assays were performed to determine cell viability. Four prostate cancer cells were seeded at the density of $1 \times 10^{3}$ cells/well in 96-well plates for $24 \mathrm{~h}$, and then fed fresh medium and treated with various doses of silibinin $(50,100$, and $200 \mu \mathrm{mol} / \mathrm{L})$ for $24,48,72$, and $96 \mathrm{~h}$. After the exposure period, $20 \mu \mathrm{L}$ MTT ( $5 \mathrm{mg} / \mathrm{mL}$ in PBS) was added to each well for $4 \mathrm{~h}$ incubation at $37^{\circ} \mathrm{C}$ in $5 \% \mathrm{CO}_{2}$. Thereafter, the medium containing MTT was removed and $150 \mu \mathrm{L}$ DMSO was added to solubilize the formazan crystals. The absorbance $(O D)$ was then measured at a wavelength of $590 \mathrm{~nm}$ by a Microplate Autoreader (Bio-Tek Instruments, VT, USA). The growth inhibitory rate was calculated by the following formula: growth inhibitory rate $=($ average $O D$ value in the control group-average $O D$ value in the treatment group)/average $O D$ value in the control group $\times 100 \%$.

\section{Cell invasion and motility assays}

For cell invasion assays ${ }^{[15]}, \mathrm{ARCaP}_{\mathrm{M}}$ cells were treated with silibinin $(50,100$, and $200 \mu \mathrm{mol} / \mathrm{L})$ for 24,48 , and $72 \mathrm{~h}$, and then cells were harvested and their in vitro invasiveness was determined using a Transwell chamber (Corning, NY, USA). Matrigel (Sigma, St Louis, MO, USA) was diluted by serum-free medium to a final concentration of $2 \mathrm{mg} / \mathrm{mL}$, and $8 \mu \mathrm{m}$ pore polycarbonate membrane filters were coated with $50 \mu \mathrm{L}$ of Matrigel. Treated cells were then seeded into the upper chamber with $5 \times 10^{3}$ cells/well in $100 \mu \mathrm{L}$ of serum-free medium, and $1 \mathrm{ml}$ medium containing 20\% FBS was added to the lower chamber as a chemoattractant. After incubation for $48 \mathrm{~h}$ at $37{ }^{\circ} \mathrm{C}$ in $5 \% \mathrm{CO}_{2}$, the Matrigel coating on the upper surface of the filter was wiped with a cotton swab. Cells that invaded to the lower surface of the filter were fixed by $4 \%$ paraformaldehyde and stained with Giemsa. Cell numbers were counted in three random fields $(\times 100)$ per filter. The cell motility assay was conducted with $2.5 \times 10^{3}$ cells/well in a similar fashion in a Transwell chamber without coating Matrigel.

\section{Wound healing assay}

To determine the effect of silibinin on migration of $\mathrm{ARCaP}_{\mathrm{M}}$ cells in vitro, cells were seeded at a density of $5 \times 10^{5}$ cells in $60 \mathrm{~mm}$-dishes and grew to about $90 \%$ confluence after $48 \mathrm{~h}$. Medium was removed and cell monolayers were wounded by manually scraping the cells with a $1 \mathrm{ml}$ plastic pipette tip. Debris was removed from the culture by washing with PBS twice, and cells were then cultured with fresh medium containing silibinin at different concentrations for 24,48 , and $72 \mathrm{~h}$. Images were captured immediately after wounding and $24 \mathrm{~h}$ post wounding, and wound closure was monitored with a UOP DSZ500X inverted microscope (UOP Microscope, Chongqing, China). Wound sizes were verified with the scale of the images to ensure that all wounds were the same width at the beginning. The migration distance and migration inhibitory rate were calculated by the following formula: migration distance $=$ (wound width at the beginning-wound width after treatment)/2 ( $\mu \mathrm{m})$; migration inhibitory rate=(average migration distance in the control group-average migration distance in the treatment group)/average migration distance in the control group $\times 100 \%$.

\section{Western blotting analysis}

After the indicated silibinin treatment, the medium was removed and $\mathrm{ARCaP}_{\mathrm{M}}$ cells were washed with cold PBS twice; then, total cellular protein lysates were prepared with RIPA buffer [50 mmol/L Tris (pH 8.0), 150 mmol/L NaCl, 0.1\% SDS, 
$1 \%$ NP40 and $0.5 \%$ sodium deoxycholate] containing proteinase inhibitors (1\% Cocktail and $1 \mathrm{mmol} / \mathrm{L}$ PMSF, both from Sigma, St Louis, MO, USA). A total of $30 \mu \mathrm{g}$ of protein was separated by $12 \%$ SDS-PAGE and transferred to nitrocellulose membranes. The membranes were blocked at room temperature for $1 \mathrm{~h}$ with $5 \%$ skim milk in Tris-buffered saline with $0.1 \%$ Tween 20 (pH 7.6, TBST). Monoclonal vimentin antibody (V9, Santa Cruz, CA, USA) was applied at 1:2000 dilutions by $5 \%$ skim milk in TBST at room temperature for $1.5 \mathrm{~h}$. After being washed with TBST, membranes were incubated with secondary antibodies coupled to horseradish peroxidase at room temperature for $1 \mathrm{~h}$ and visualized with a ECL chemiluminescent detection system (Pierce, Rockford, IL, USA). Loading differences were normalized using a monoclonal GAPDH antibody. The mean density for each band was analyzed using Glyko BandScan software (Glyko, Novato, USA).

\section{Immunofluorescence staining}

After the indicated silibinin treatment, $\mathrm{ARCaP}_{\mathrm{M}}$ cells on coverslips were washed with PBS and fixed in $4 \%$ paraformaldehyde for $20 \mathrm{~min}$. Cells were permeabilized with PBS containing $0.25 \%$ Triton X-100 for 30 min and blocked with horse serum for $20 \mathrm{~min}$. Cells were then incubated with a 1:1000 dilution of monoclonal vimentin antibody in PBS buffer containing $10 \%$ bovine serum overnight at $4{ }^{\circ} \mathrm{C}$ and washed and incubated with a 1:200 dilution of TRITC conjugated antimouse IgG. The specimens were observed under Olympus IX-50 fluorescence inverted microscope (Olympus, Tokyo, Japan).

\section{Reverse transcription-polymerase chain reaction (RT-PCR)}

After the indicated silibinin treatment, total RNA was isolated from $\mathrm{ARCaP}_{\mathrm{M}}$ cells using Trizol reagent (Invitrogen, Carlsbad, CA, USA) and quantitated by absorbance at 260 $\mathrm{nm}$. The RNA $(2 \mu \mathrm{g})$ was reverse transcribed using RevertAid $^{\mathrm{TM}}$ First Strand cDNA Synthesis Kit (MBI Fermentas, St Leon-Rot, Germany) according to the manufacturer's instructions. All PCR analyses were subsequently performed with $2 \mu \mathrm{L}$ of the cDNA reaction utilizing conditions as follows: $94{ }^{\circ} \mathrm{C}, 5 \mathrm{~min}, 32$ cycles of $94{ }^{\circ} \mathrm{C}, 30 \mathrm{~s} ; 58^{\circ} \mathrm{C}, 30 \mathrm{~s} ; 72{ }^{\circ} \mathrm{C}, 45 \mathrm{~s}$. Reactions were finished with $72{ }^{\circ} \mathrm{C}, 7$ min extension. Primers were used for MMP-2, MMP-9, uPA, and $\beta$-actin: MMP-2 (475 bp): 5'-GGCCCTGTCACTCCTGAGAT-3' (forward) and 5'-GGCATCCAGGTTATCGGGGA-3' (reverse); MMP-9 (482 bp): 5'-CAACATCACCTATTGGATCC-3' (forward) and 5'-CGGGTGTAGAGTCTCTCGCT-3' (reverse); uPA (348 bp): 5'-TTGCGGCCATCTACAGGAG-3' (forward) and $5^{\prime}$-ACTGGGGATCGTTATACATC-3' (reverse); $\beta$-actin (318 bp): $5^{\prime}$-ATCATGTTTGAGACCTTCAACA-3' (forward) and 5'-CATCTCTTGCTCGAAGTCCA-3' (reverse). PCR products were analyzed by $2 \%$ agarose gel electrophoresis and visualized using ethidium bromide staining. The mean density for each band was also analyzed using Glyko BandScan software.

\section{Statistical analysis}

All assays were repeated in triplicate in three independent experiments, and all data were expressed as means \pm SEM. Analysis of variance (ANOVA) for multiple comparisons was used as noted. In all cases, $P<0.05$ was considered significant. All statistical tests were performed with statistical analysis software (SPSS, Chicago, IL, USA).

\section{Results}

Decreased sensitivity of $\mathrm{ARCaP}_{M}$ cells to growth inhibition by silibinin

We exposed four human prostate cancer cell lines (LNCaP, $\mathrm{PC}-3$, DU145, and $\mathrm{ARCaP}_{\mathrm{M}}$ ) to increasing concentrations of silibinin for different time periods and compared their relative sensitivities to the growth inhibition of silibinin by MTT assay. These cells displayed marked heterogeneity in responsiveness. Consistent with the previous data ${ }^{[5-7]}$, silibinin significantly inhibited the cell proliferation of LNCaP, PC-3, and DU145 cells in a dose- and time-dependent manner, whereas it had a weaker inhibitory effect on the cell viability of $\mathrm{ARCaP}_{\mathrm{M}}$ cells (Figure 1). In dose-dependent experiments, the lower dose of $50 \mu \mathrm{mol} / \mathrm{L}$ silibinin could reduce the cell viabilities of LNCaP, PC-3, and DU145 cells by $18.5 \%, 26.7 \%$, and $15.0 \%$, respectively, whereas only $0.7 \%$ growth inhibition was observed in $\mathrm{ARCaP}_{\mathrm{M}}$ cells after $48 \mathrm{~h}$ of treatment. Even at a concentration as high as $200 \mu \mathrm{mol} / \mathrm{L}$, only $18.5 \%$ growth inhibition was
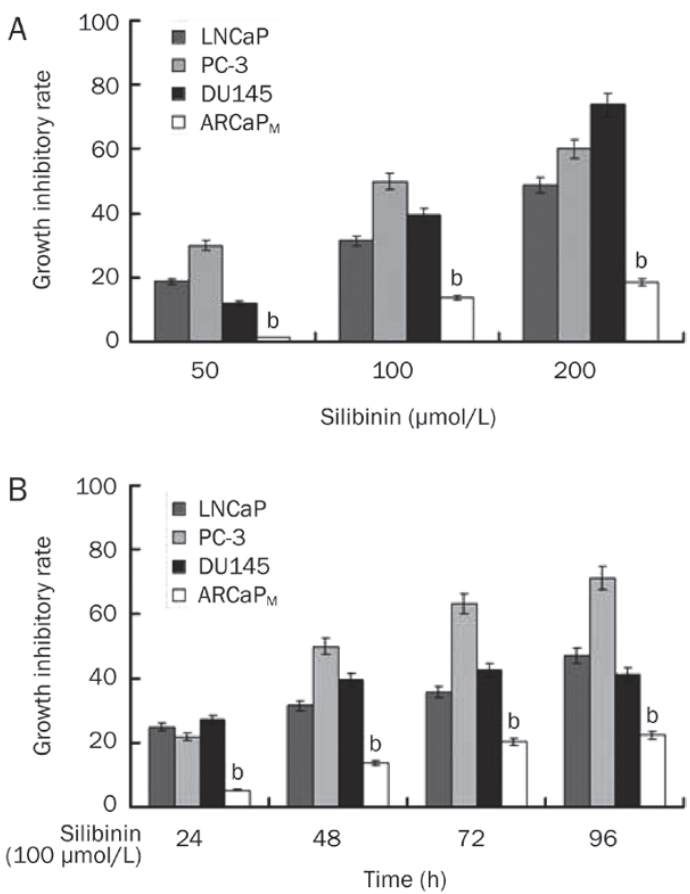

Figure 1. Different sensitivities of prostate cancer cell lines to growth inhibition by silibinin. After cells were treated with the indicated doses of silibinin (50, 100, and $200 \mu \mathrm{mol} / \mathrm{L})$ for $24,48,72$, and $96 \mathrm{~h}$, cell viabilities were determined by MTT assay. (A) Different growth inhibition of LNCaP, PC-3, DU145, and ARCaP ${ }_{M}$ cells to silibinin in a dose-dependent manner. (B) Different growth inhibition of LNCaP, PC-3, DU145, and $\mathrm{ARCaP}_{\mathrm{M}}$ cells to silibinin in a time-dependent manner. The data shown are means \pm SEM of three independent experiments. ${ }^{b} P<0.05$ compared with LNCaP, PC-3, and DU145 cells. 
observed in $\mathrm{ARCaP}_{\mathrm{M}}$ cells, but $48.7 \%, 60.0 \%$, and $73.8 \%$ in LNCaP, PC-3, and DU145 cells, respectively (Figure 1A). Similarly, in time-course experiments, $100 \mu \mathrm{mol} / \mathrm{L}$ silibinin treatment for $24 \mathrm{~h}$ led to $24.8 \%, 21.8 \%$, and $27.3 \%$ growth inhibition of LNCaP, PC-3, and DU145 cells, respectively, but only 5.3\% of $\mathrm{ARCaP}_{\mathrm{M}}$ cells. The growth inhibition reached its maximum at $96 \mathrm{~h}$, and $100 \mu \mathrm{mol} / \mathrm{L}$ silibinin treatments resulted in $47.2 \%$, $71.3 \%$, and $41.1 \%$ growth inhibition of LNCaP, PC-3, and DU145 cells, respectively, but only $22.2 \%$ of $\mathrm{ARCaP}_{\mathrm{M}}$ cells (Figure 1B). These data indicated that highly metastatic $\mathrm{ARCaP}_{\mathrm{M}}$ cells were less sensitive to growth inhibition by silibinin than LNCaP, PC-3, and DU145 cells.

Inhibition on invasion, motility and migration of $\mathrm{ARCaP}_{\mathrm{M}}$ cells by silibinin

Using a Transwell chamber coated with or without Matrigel, we found that silibinin could significantly reduce the invasion and motility of $\mathrm{ARCaP}_{\mathrm{M}}$ cells (Figure 2). As low as $37 \%$ of the invasive capability and $50 \%$ of motility capability were retained after $100 \mu \mathrm{mol} / \mathrm{L}$ silibinin treatment for $48 \mathrm{~h}$ (Figure 2A). Moreover, this tremendous inhibitory effect occurred in a dose- and time-dependent manner. Different concentrations of silibinin $(50,100$, and $200 \mu \mathrm{mol} / \mathrm{L})$ after $48 \mathrm{~h}$ treatment reduced the invasion of $\mathrm{ARCaP}_{\mathrm{M}}$ by $15 \%, 63 \%$, and $92 \%$ and reduced the motility by $20 \%, 50 \%$, and $25 \%$ (Figure $2 \mathrm{~B}$ ). As such, $100 \mu \mathrm{mol} / \mathrm{L}$ silibinin for 24,48 , and $72 \mathrm{~h}$ reduced the invasion of $\mathrm{ARCaP}_{\mathrm{M}}$ cells by $41 \%, 53 \%$, and $87.5 \%$, respectively, and reduced the motility by $35 \%, 50 \%$, and $75 \%$, respectively (Figure 2C).

Additionally, we also obtained similar results in a wound healing assay. Silibinin inhibited migration in vitro for $\mathrm{ARCaP}_{\mathrm{M}}$ cells (Figure 3). After treatment with $200 \mu \mathrm{mol} / \mathrm{L}$ silibinin for $72 \mathrm{~h}$, the cells remained creviced, whereas the wounds with mock treatment healed completely (Figure 3A). This inhibitory effect was dose- and time-dependent (Figure $3 \mathrm{~B}$ ). In a quantitative analysis, different concentrations of silibinin (50, 100, and $200 \mu \mathrm{mol} / \mathrm{L})$ after $24 \mathrm{~h}$ treatment reduced the migration of $\mathrm{ARCaP}_{\mathrm{M}}$ cells by $45 \%, 70.1 \%$, and $85 \%$, respectively. Similarly, after $72 \mathrm{~h}$ of treatment with 50, 100, and $200 \mu \mathrm{mol} / \mathrm{L}$ silibinin, 30.6\%, 47.2\%, and 69.4\% inhibition of migration was observed in $\mathrm{ARCaP}_{\mathrm{M}}$ cells. Our results strongly suggest that pharmacological doses of silibinin could lead to significant inhibition of invasion, motility and migration of $\mathrm{ARCaP}_{\mathrm{M}}$ cells.

\section{Silibinin inhibits vimentin and MMP-2 expression in $\mathrm{ARCaP}_{\mathrm{M}}$ cells} To elucidate the possible underlying mechanisms of antimetastatic activities of silibinin on $\mathrm{ARCaP}_{\mathrm{M}}$ cells, we detected changes in vimentin, MMP-2, MMP-9, and uPA expression by Western blotting, immunofluorescence staining and RT-PCR. As shown in Figure 4, Western blotting revealed silibinin treatment significantly decreased the expression of vimentin in a dose- and time-dependent manner when GAPDH served as a loading control (Figure $4 \mathrm{~A}$ and $4 \mathrm{~B}$ ). Treatment with 50, 100 , and $200 \mu \mathrm{mol} / \mathrm{L}$ of silibinin after $24 \mathrm{~h}$ showed $32.4 \%$, $54.9 \%$, and $79 \%$ decreases in vimentin protein compared
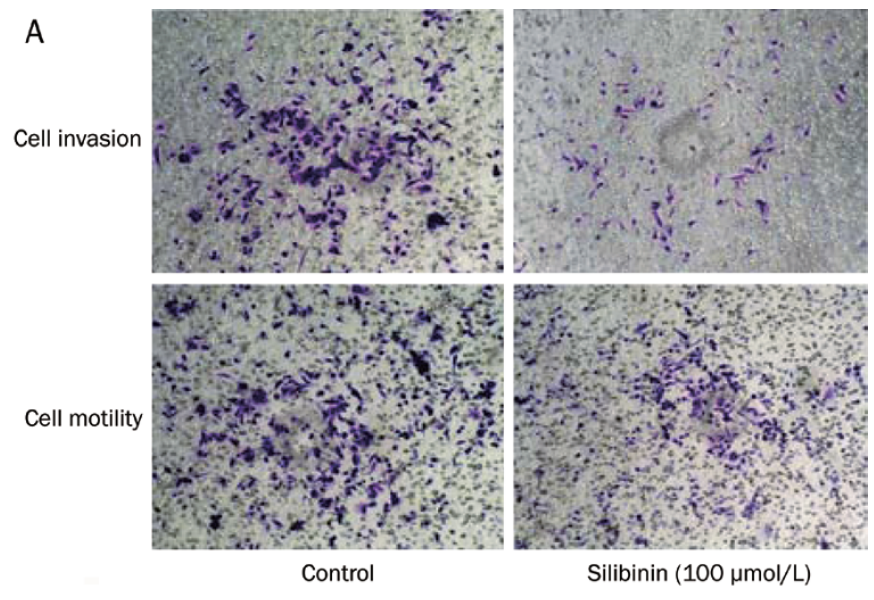

B
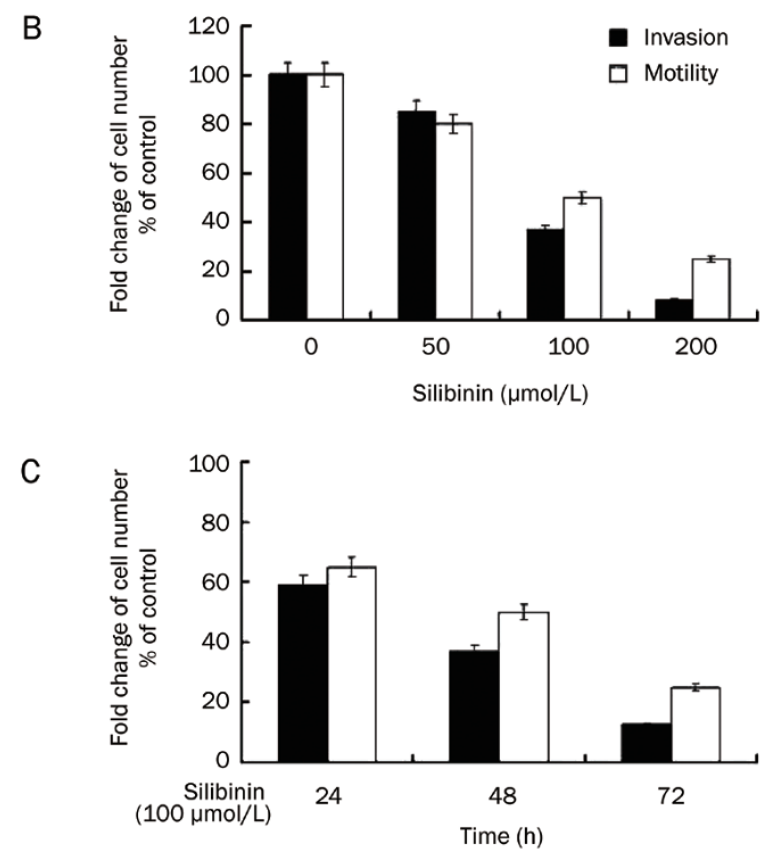

Figure 2. Dose- and time-dependent inhibitory effects of silibinin on the invasion and motility of $\mathrm{ARCaP}_{\mathrm{M}}$ cells. $\mathrm{ARCaP}_{\mathrm{M}}$ cells were treated with different concentrations of silibinin $(50,100$, and $200 \mu \mathrm{mol} / \mathrm{L})$ for 24 , 48 , and $72 \mathrm{~h}$ and then harvested and seeded into the upper chamber, either coated or uncoated with Matrigel. The number of cells that invaded or moved into the lower chamber represented the invasion and motility capabilities. (A) Invasion and motility inhibition of $\mathrm{ARCaP}_{\mathrm{M}}$ cells after $100 \mu \mathrm{mol} / \mathrm{L}$ silibinin treatment for $48 \mathrm{~h}$ (magnification $\times 100$ ). (B and C) Silibinin inhibited the invasion and motility of $\mathrm{ARCaP}_{\mathrm{M}}$ cells in a doseand time-dependent manner. Data represent means \pm SEM of three independent experiments.

with controls; $100 \mu \mathrm{mol} / \mathrm{L}$ silibinin treatment for 24, 48, and $72 \mathrm{~h}$ showed $58.6 \%, 74.3 \%$, and $86.9 \%$ decreases in vimentin protein. Furthermore, we observed the similar decreasing tendency of vimentin in the cytoplasm after $100 \mu \mathrm{mol} / \mathrm{L}$ silibinin treatment by immunofluorescence staining (Figure 4C). In addition, $100 \mu \mathrm{mol} / \mathrm{L}$ silibinin treatment for 24,48 , and $72 \mathrm{~h}$ decreased MMP-2 mRNA by $42.3 \%, 34.5 \%$, and $33.3 \%$, 


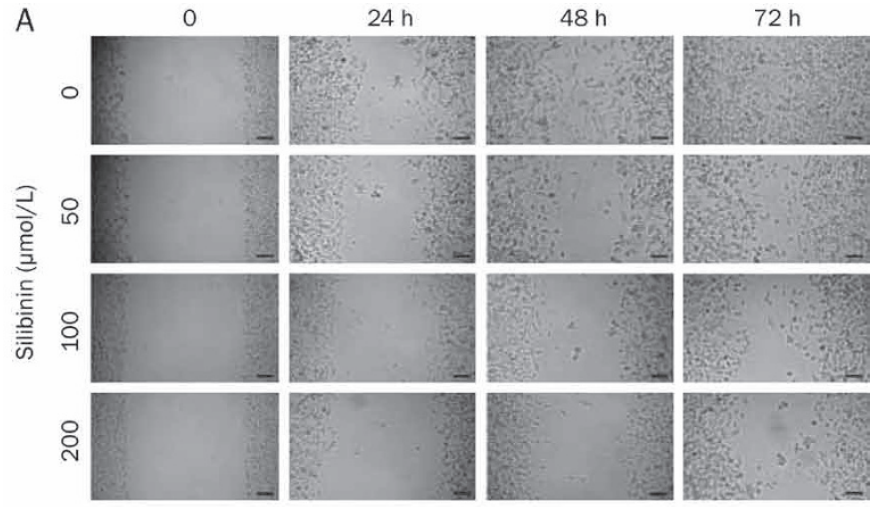

B

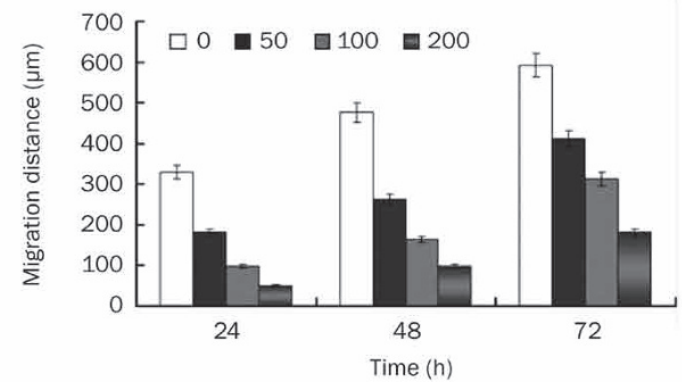

Figure 3. Dose- and time-dependent inhibitory effects of silibinin on migration of $\mathrm{ARCaP}_{\mathrm{M}}$ cells in vitro. The confluent $\mathrm{ARCaP}_{\mathrm{M}}$ monolayers were wounded by scraping and treated with silibinin (50, 100, and $200 \mu \mathrm{mol} / \mathrm{L})$. Cell migration to the wound surface was monitored after 24,48 , and $72 \mathrm{~h}$. A representative image is shown (magnification $\times 100$ ), and the average migration distances of the wound edge in three independent experiments are quantitated below the photograph data. Bar represents $200 \mu \mathrm{m}$.

but had no significant effects on MMP-9 and uPA mRNA expression when $\beta$-actin served as a loading control (Figure $4 \mathrm{D})$. Together, these findings suggest that down-regulation of vimentin and MMP-2 might be involved in the inhibition of invasion, motility and migration of $\mathrm{ARCaP}_{\mathrm{M}}$ cells after silibinin treatment.

\section{Discussion}

In this study, utilizing a well-characterized prostate cancer cell line, we have demonstrated a novel anticancer effect of silibinin and provided possible mechanisms that are responsible for its anti-metastatic effect in vitro.

The anti-proliferative effect of silibinin has been well documented in the androgen-dependent and androgenindependent prostate cancer LNCaP, 22Rv1, PC-3, and DU145 cell lines, and studies have shown that silibinin could inhibit the growth of prostate cancer by inducing cell cycle arrest or caspase-dependent apoptosis ${ }^{[5-7]}$. In agreement with previous studies, we also observed strong inhibitory effects of silibinin on LNCaP, PC-3, and DU145 cell proliferation, whereas $\mathrm{ARCaP}_{\mathrm{M}}$ cells showed a much weaker response to the antiproliferative effect of silibinin. As a derivative subclone from androgen-repressed prostate cancer, $\mathrm{Xu}$ et al have demonstrated that $\mathrm{ARCaP}_{\mathrm{M}}$ cells exhibited an aggressive mesenchy- mal phenotype, which was fast-growing and more resistant to chemotherapeutic drugs, such as doxorubicin, etoposide and paclitaxel ${ }^{[14]}$. Here, we revealed that $\mathrm{ARCaP}_{\mathrm{M}}$ cells showed stronger resistance to growth inhibition following silibinin treatment.

Several studies have silibinin might represent a potential anti-metastatic agent inhibiting cancer cell invasion and motility, and this efficacy has been demonstrated in A549 lung cancer cells, SCC-4 tongue cancer cells, osteosarcoma MG-63 cells and MCF-7 breast cancer cells ${ }^{[16-20]}$. Recently, it has been reported that silibinin exerts inhibitory effects by silibinin on viability, migration and adhesion of androgen-independent PC-3 cells, such that a2 $\beta 1$-integrin may be the target ${ }^{[11]}$. Singh et al also found that silibinin treatment inhibited prostate tumor growth, progression, local invasion and distant metastasis using the TRAMP mouse model ${ }^{[12]}$. Here, we are the first to show that pharmacological doses of silibinin may exert inhibitory effects on the invasion, motility and migration of $\mathrm{ARCaP}_{\mathrm{M}}$ cells in a dose- and time-dependent manner.

To investigate the molecular effects of silibinin treatment on $\mathrm{ARCaP}_{\mathrm{M}}$ cells, we further analyzed the alterations of several molecules related to cancer invasion and metastasis, such as vimentin, MMP-2, MMP-9, and uPA. Vimentin is a mammalian structural cytoskeletal protein constituting type III mesenchymal filaments, and its elevated and aberrant expression correlates well with up-regulated cell invasion or migration both in the embryo and in malignancy ${ }^{[21]}$. Several studies have shown that vimentin could affect the invasion and motility of prostate cancer cells and is a promising marker for predicting aggressive and metastatic prostate cancer ${ }^{[22-23]}$. Consistent with their highly metastatic features, $\mathrm{ARCaP}_{\mathrm{M}}$ cells display higher expression of vimentin and other mesenchymal markers ${ }^{[14]}$. Here, it was demonstrated that silibinin markedly decreased vimentin protein expression in a dose- and timedependent manner. Similar results were reported in Singh's findings, which revealed anti-metastatic activities of silibinin in TRAMP mice together with a concomitant strong decrease in the level of vimentin ${ }^{[12]}$.

In addition, we found silibinin significantly suppressed MMP-2 expression, but not MMP-9 or uPA in $\mathrm{ARCaP}_{\mathrm{M}}$ cells. MMPs are known proteolytic enzymes that degrade the extracellular matrix and basement membrane of cells, and MMP-2 and MMP-9 are the most vital enzymes for degradation ${ }^{[24,25]}$. Therefore, they are considered major factors in tumor invasion and metastasis. uPA, which is an upstream enzyme of MMPs, might activate a series of protein degradation reactions to regulate or activate $\mathrm{MMPs}^{[26]}$. A series of studies demonstrated that silibinin could inhibit invasion and motility of A549 cells and SCC- 4 cells by down-regulating MMP-2 and UPA and up-regulating tissue inhibitor of metalloproteinase-2 (TIMP2) and PAI-1 expressions ${ }^{[16,17]}$. Moreover, in A549 lung cancer cells, silibinin inhibited MMP-2 and uPA expression through reducing ERK1/2 and Akt phosphorylation ${ }^{[18]}$. In human osteosarcoma MG-63 cells, silibinin inhibited uPA and MMP-2 expressions, IL-6-induced ERK1/2 and c-Jun phosphorylation, and cell invasiveness ${ }^{[19]}$. In addition, silibinin also reduced 
A
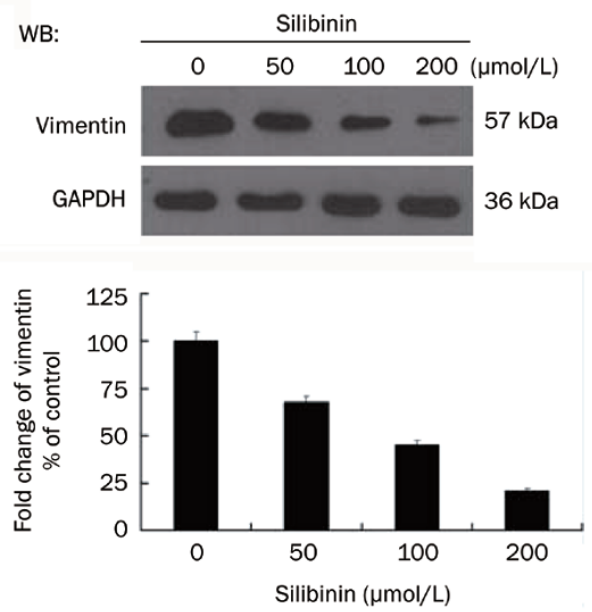

C

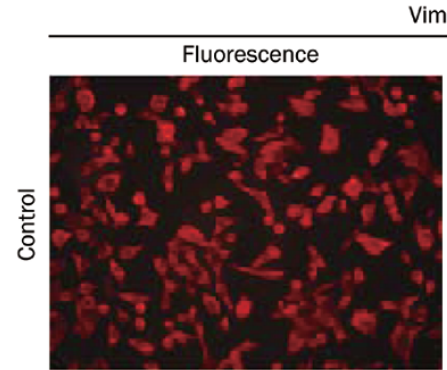

Vimentin

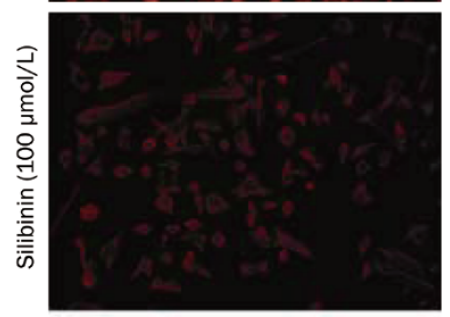

B WB:
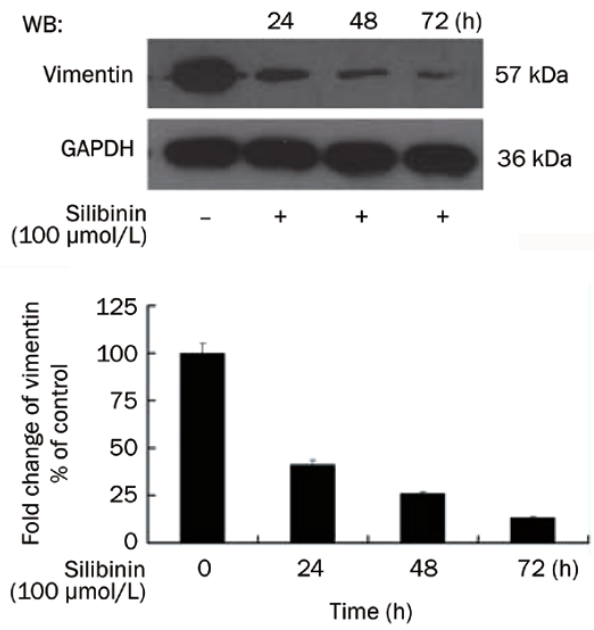

D
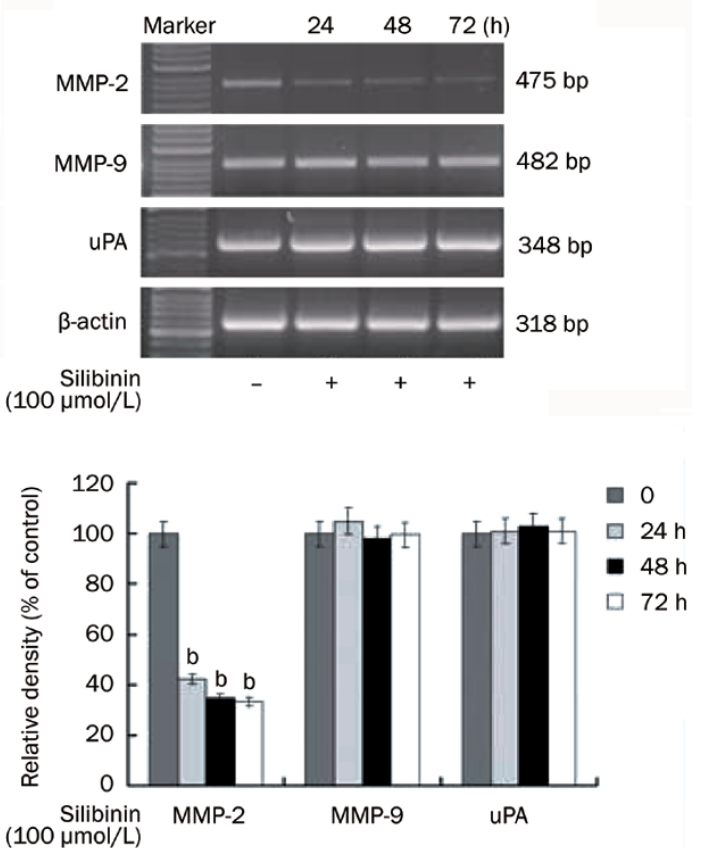

Figure 4. Inhibitory effects of silibinin on the expression of vimentin and MMP-2 in ARCaP ${ }_{M}$ cells. (A and B) Cells were treated with the indicated doses of silibinin $(50,100$, and $200 \mu \mathrm{mol} / \mathrm{L})$ for 24,48 , and $72 \mathrm{~h}$, and then cell lysates were subjected to SDS-PAGE followed by Western blotting. Membranes were probed for vimentin protein levels, and GAPDH served as a loading control. Quantitative results were quantitated below the gel data. (C) Cells were treated with DMSO (control) or $100 \mu \mathrm{mol} / \mathrm{L}$ silibinin for $24 \mathrm{~h}$, and the change of vimentin expression was evaluated by immunofluorescence staining (magnification $\times 200$ ). (D) Cells were treated with $100 \mu \mathrm{mol} / \mathrm{L}$ silibinin for 24,48 , and $72 \mathrm{~h}$, and then total mRNA was subjected to RT-PCR for analyzing the changes of MMP-2, MMP-9, and UPA expression. $\beta$-actin served as a loading control. Quantitative analyses are shown below the gel data. Data represent means \pm SEM of three independent experiments. ${ }^{\mathrm{b}} P<0.05$ compared with control.

PMA-induced invasion of MCF-7 breast cancer cells through the specific inhibition of AP-1-dependent MMP-9 gene expres$\operatorname{sion}^{[20]}$. In our studies, we observed a suppression effect of silibinin on MMP-2 expression, but not MMP-9 or uPA in $\mathrm{ARCaP}_{\mathrm{M}}$ cells. Thus, it is possible that silibinin could suppress prostate cancer invasion and metastasis through the inhibition of vimentin and MMP-2 expression.

In conclusion, here we are the first to demonstrate a novel mechanism by which silibinin acts as an anti-metastatic agent via inhibiting invasion, motility and migration in novel, highly bone metastatic $\mathrm{ARCaP}_{\mathrm{M}}$ cells by down-regulating the vimentin and MMP-2 expression. Furthermore, we will use nude mice to verify the in vivo anti-metastatic effects of silibinin in human prostate cancer and explore additional molecular mechanisms of silibinin on prostate cancer bone metastasis.

\section{Acknowledgments}

This project is supported in part by the National 863 project of China (№ 2006AA020705). We thank Prof Jin-tang DONG (Emory University School of Medicine, Atlanta, GA, USA) and 
Jer-Tsong HSIEH (University of Texas Southwestern Medical Center, Dallas, TX, USA) for their helpful discussion and support.

\section{Author contribution}

Kai-jie WU, Jin ZENG, and Da-lin HE designed this research; Kai-jie WU, Guo-dong ZHU, Lin-lin ZHANG, and Dong ZHANG performed this research, Lei LI, Jin-hai FAN, and Xinyang WANG contributed new analytical tools and reagents; Kai-jie WU and Jin ZENG analyzed data, wrote and revised the paper.

\section{References}

1 Landis SH, Murray T, Bolden S, Wingo PA. Cancer statistics, 1999. CA Cancer J Clin 1999; 49: 8-31.

2 Feldman BJ, Feldman D. The development of androgen-independent prostate cancer. Nat Rev Cancer 2001; 1: 34-45.

3 Surh YJ. Cancer chemoprevention with dietary phytochemicals. Nat Rev Cancer 2003; 3: 768-80.

4 Singh RP, Agarwal R. Prostate cancer prevention by Silibinin. Curr Cancer Drug Targets 2004; 4: 1-11.

5 Tyagi A, Agarwal C, Agarwal R. Inhibition of retinoblastoma protein (Rb) phosphorylation at serine sites and an increase in Rb-E2F complex formation by silibinin in androgen-dependent human prostate carcinoma LNCaP cells: role in prostate cancer prevention. Mol Cancer Ther 2002; 1: 525-32.

6 Deep G, Singh RP, Agarwal C, Kroll DJ, Agarwal R. Silymarin and silibinin cause G1 and G2-M cell cycle arrest via distinct circuitries in human prostate cancer PC-3 cells: a comparison of flavanone silibinin with flavanolignan mixture silymarin. Oncogene 2006; 25: 1053-69.

7 Zi X, Grasso AW, Kung HJ, Agarwal R. A flavonoid antioxidant, silymarin, inhibits activation of erbB1 signaling and induces cyclindependent kinase inhibitors, G1 arrest, and anticarcinogenic effects in human prostate carcinoma DU145 cells. Cancer Res 1998; 58: 1920-9.

8 Singh RP, Deep G, Blouin MJ, Pollak MN, Agarwal R. Silibinin suppresses in vivo growth of human prostate carcinoma PC-3 tumor xenograft. Carcinogenesis 2007; 28: 2567-74.

9 Singh RP, Dhanalakshmi S, Tyagi AK, Chan DC, Agarwal C, Agarwal R. Dietary feeding of silibinin inhibits advance human prostate carcinoma growth in athymic nude mice and increases plasma insulinlike growth factor-binding protein-3 levels. Cancer Res 2002; 62: 3063-9.

10 Raina K, Blouin MJ, Singh RP, Majeed N, Deep G, Varghese L, et al. Dietary feeding of silibinin inhibits prostate tumor growth and progression in transgenic adenocarcinoma of the mouse prostate model. Cancer Res 2007; 67: 11083-91.

11 Mokhtari MJ, Motamed N, Shokrgozar MA. Evaluation of silibinin on the viability, migration and adhesion of the human prostate adenocarcinoma (PC-3) cell line. Cell Biol Int 2008; 32: 888-92.

12 Singh RP, Raina K, Sharma G, Agarwal R. Silibinin inhibits established prostate tumor growth, progression, invasion, and metastasis and suppresses tumor angiogenesis and epithelial-mesenchymal transition in transgenic adenocarcinoma of the mouse prostate model mice. Clin Cancer Res 2008; 14: 7773-80.

13 Boring CC, Squires TS, Tong T, Montgomery S. Cancer statistics, 1994. CA Cancer J Clin 1994; 44: 7-26.

$14 \mathrm{Xu} \mathrm{J}$, Wang R, Xie ZH, Odero-Marah V, Pathak S, Multani A, et al. Microenvironment in promoting epithelial to mesenchymal transition and increased bone and adrenal gland metastasis. Prostate 2006; 66: 1664-73.

15 Attiga FA, Fernandez PM, Weeraratna AT, Manyak MJ, Patierno SR. Inhibitors of prostaglandin synthesis inhibit human prostate tumor cell invasiveness and reduce the release of matrix metalloproteinases. Cancer Res 2000; 60: 4629-37.

16 Chu SC, Chiou HL, Chen PN, Yang SF, Hsieh YS. Silibinin inhibits the invasion of human lung cancer cells via decreased productions of urokinase-plasminogen activator and matrix metalloproteinase-2. Mol Carcinogen 2004; 40: 143-9.

17 Chen PN, Hsieh YS, Chiang CL, Chiou HL, Yang SF, Chu SC. Silibinin inhibits invasion of oral cancer cells by suppressing the MAPK pathway. J Dent Res 2006; 85: 220-5.

18 Chen PN, Hsieh YS, Chiou HL, Chu SC. Silibinin inhibits cell invasion through inactivation of both PI3K-Akt and MAPK signaling pathways. Chem-Biol Interact 2005; 156: 141-50.

19 Hsieh YS, Chu SC, Yang SF, Chen PN, Liu YC, Lu KH. Silibinin suppresses human osteosarcoma MG-63 cell invasion by inhibiting the ERK-dependent c-Jun/AP-1 induction of MMP-2. Carcinogenesis 2007; 28: 977-87.

20 Lee SO, Jeong YJ, Im HG, Kim CH, Chang YC, Lee IS. Silibinin suppresses PMA-induced MMP-9 expression by blocking the AP-1 activation via MAPK signaling pathways in MCF-7 human breast carcinoma cells. Biochem Biophys Res Commun 2007; 354: 165-71.

21 Kokkinos MI, Wafai R, Wong MK, Newgreen DF, Thompson EW, Waltham M. Vimentin and epithelial to mesenchymal transition in human breast cancer: observations in vitro and in vivo. Cells Tissues Organs 2007; 185: 191-203.

22 Zhao Y, Yan Q, Long X, Chen X, Wang Y. Vimentin affects the mobility and invasiveness of prostate cancer cells. Cell Biochem Funct 2008; 26: $571-7$.

23 Lang SH, Hyde C, Reid IN, Hitchcock IS, Hart CA, Bryden AA, et al. Enhanced expression of Vimentin in motile prostate cancer cell lines and in poorly differentiated and metastatic prostate carcinoma. Prostate 2002; 52: 253-63.

24 Nelson AR, Fingleton B, Rothenberg ML, Matrisian LM. Matrix metalloproteinases: biologic activity and clinical implications. J Clin Oncol 2000; 18: 1135-49.

25 Chambers AF, Matrisian LM. Changing views of the role of matrix metalloproteinases in metastasis. J Natl Cancer Inst 1997; 89: 1260-70.

26 Lijnen HR. Matrix metalloproteinases and cellular fibrinolytic activity. Biochemistry 2002; 67: 92-8. 